\title{
Analisis Sebaran Lahan Kritis Kawasan Hutan Pada Daerah Aliran Sungai (DAS) Pengabuan
}

\author{
Agus Kurniawan Mastur ${ }^{1 *}$, Eva Achmad ${ }^{2}$, dan Joko Asmoro Hadi² \\ ${ }^{1}$ Program Studi Agroekoteknologi Fakultas Pertanian Universitas Jambi \\ ${ }^{2}$ Program Studi Kehutanan Fakultas Pertanian Universitas Jambi \\ Jl. Lintas Jambi - Muara Bulian KM 15 Mendalo Indah Kabupaten Muaro Jambi, Jambi. \\ *e_mail: agus_kurniawan@unja.ac.id
}

\begin{abstract}
Land use that is not based on its capacity will has impact on land quality decreasing. This will lead to the emerging of critical land. This study aimed to analyze the critical level of forest area in the Pengabuan watershed. Critical land analysis was based on the Regulation of the Director General of Watershed Management and Social Forestry Number P.4/V-SET/2013. There were 4 parameters used, namely: land cover, erosion hazard level, slope and management aspects. Land cover was the main parameter in determining critical land because it had the largest weight. Geographic Information System (GIS) and remote sensing technique were used in data processing and analyzing in order to determine the critical level of land. The results showed that $50.58 \%$ of the land in the Pengabuan watershed forest area was classified as moderately critical (95,030.7 ha). Land with potentially critical criteria covering an area of 17,804 ha (75.19\%) dominated forest areas within protected areas. Approximately $2.71 \%(4,457.6 \mathrm{ha})$ of the forest area with open land cover from forest areas outside protected areas was categorised as higly critical land.
\end{abstract}

Keywords: critical land; GIS; landcover; Pengabuan watershed.

\section{Pendahuluan}

Lahan merupakan faktor utama untuk memenuhi kebutuhan hidup. Pemanfaatan lahan diutamakan pada lahan yang berproduktivitas. Ketersediaan lahan dengan kemampuan produktivitas tinggi semakin berkurang seiring dengan upaya pemenuhan kebutuhan manusia. Renyut et al., (2018) menyebutkan bahwa sumber daya lahan menjadi sangat penting, seiring dengan bertambahnya jumlah penduduk. Konversi lahan merupakan tindakan yang tidak dapat dihindari sehingga menimbulkan permasalahan baru.

Penggunaan lahan yang tidak sesuai dengan kemampuan akan mengakibatkan degradasi lahan (Rosyada $e t$ al., 2015; Kubangun et al., 2016). Selanjutnya, Harijanto (2016) juga menyatakan bahwa praktek tanpa menerapkan konservasi yang tepat telah menyebabkan tingginya erosi. Exploitasi sumberdaya lahan secara berlebihan tanpa mempertimbangkan kaidah konservasi menjadi pemicu peningkatan luasan lahan kritis. Dijelaskan Ruhama (2020), bahwa tataguna lahan yang tidak mempertimbangkan konservasi berpotensi menimbulkan lahan kritis. Menurut Indrihasturi et al., (2016), dampak lahan kritis yaitu penurunan kualitas tanah hingga menurunkan fungsi konservasi.

Penilaian kualitas lahan dapat dianalisa dari unit kesatuan hidrologi yaitu Daerah Aliran Sungai (DAS). Kerusakan kawasan DAS dapat dideteksi dari salah satu sistem yang sangat berpengaruh yaitu pola penggunaan lahan. Anasiru (2016) menyatakan DAS adalah suatu ekosistem yang kompleks, yang mana kualitas lahan sangat ditentukan oleh kegiatan penggunaan lahan. Lebih lanjut dijelaskan Ali et al., (2015), sebagai ekosistem DAS, perubahan yang terjadi di hulu akan mempengaruhi bagian lain dari suatu DAS. Suatu DAS berfungsi mengalirkan air yang jatuh dalam kawasannya. Jika air tidak mampu berinfiltrasi, maka akan menjadi aliran permukaan dan pada akhirnya menyebabkan erosi. Kondisi lahan yang demikian merupakan ciri dari lahan yang sudah tergolong kritis.
Salah satu DAS di Provinsi Jambi yaitu DAS Pengabuan yang berada di Kabupaten Tanjung Jabung Barat. DAS Pengabuan terletak di Bagian Timur Provinsi Jambi dan merupakan bufferzone dari landscape Provinsi Jambi. Berdasarkan data fungsi kawasan yang diperoleh dari Balai Pengelolaan Daerah Aliran Sungai dan Hutan Lindung (BPDASHL) Batanghari, DAS Pengabuan terdiri dari: kawasan fungsi lindung, kawasan fungsi produksi dan areal penggunaan lain. Kawasan fungsi lindung meliputi: Taman Nasional Bukit Tiga Puluh (TNBT) dan Hutan Lindung Gambut (HLG) Bram Itam. Sedangkan pada fungsi produksi meliputi: hutan produksi dan hutan produksi terbatas.

Dalam kurun 10 tahun terakhir, kualitas DAS Pengabuan terus mengalami penurunan akibat adanya alih fungsi lahan. Berdasarkan hasil penelitian Kusuma (2019), pada periode tahun 1996 sampai tahun 2017 DAS Pengabuan mengalami penurunan luas hutan sekunder yang sangat signifikan yaitu sebesar $53,38 \% \quad(11.186,47$ ha/tahun). Sedangkan untuk tutupan lahan pemukiman, hutan tanaman dan perkebunan mengalami kenaikan yang cukup signifikan. Kegiatan alih fungsi lahan dari hutan sekunder dapat mengkibatkan peningkatan luas lahan kritis. Berdasarkan data dari Kementerian Lingkungan Hidup dan Kehutanan tahun 2018, luas lahan kritis nasional sebesar 14 juta ha yang tersebar di semua provinsi dan di Provinsi Jambi lahan kritis telah mencapai angka 213.985 ha.

Keterbaruan data penutupan lahan menjadi sumber data yang akurat untuk analisis sebaran lahan kritis. Penggunaan teknologi Sistem Informasi Geografis (SIG) dan penginderaan jauh merupakan metode yang tepat, cepat dan efisien dalam menginterpretasi tutupan lahan (Chowdhury et al., 2020). Identifikasi sebaran lahan kritis perlu dilakukan untuk perencanaan pengolahan kawasan hutan lebih lanjut. Kajian ini bertujuan untuk memberikan gambaran sebaran lahan kritis kawasan hutan di DAS Pengabuan. Berdasarkan uraian diatas perlu dilakukan pemetaan sebaran lahan kritis kawasan hutan di DAS Pengabuan. 


\section{Metode Penelitian}

Penelitian dilaksanakan di DAS Pengabuan Kabupaten Tanjung Barat, Provinsi Jambi selama 4 bulan, yaitu dari bulan September sampai Desember 2019. Peralatan yang digunakan adalah Global Positioning System (GPS), kompas, kamera, alat tulis dan komputer. Bahan yang digunakan yaitu: Citra Landsat 8 dengan path/row 122/065 dan 121/065, Peta Batas DAS, Peta Kemiringan Lereng, Peta Fungsi Kawasan dan Peta Tingkat Bahaya Erosi.

Analisis sebaran lahan kritis berpedoman pada Peraturan Direktur Jenderal Bina Pengelolaan Daerah Aliran Sungai dan Perhutanan Sosial Nomor P.4/V-SET/2013 tentang Petunjuk Teknis Penyusunan Data Spasial Lahan Kritis. Penentuan lahan kritis diklasifikasikan atas 3 fungsi kawasan, yaitu: kawasan hutan lindung, kawasan budidaya pertanian dan kawasan lindung diluar kawasan hutan. Penelitian ini fokus dilakukan pada 2 fungsi kawasan yaitu: kawasan hutan lindung dan kawasan lindung diluar kawasan hutan. Peta Batas DAS Pengabuan dipotong dengan Peta Fungsi Kawasan untuk mendeliniasi batas areal kajian yaitu kawasan hutan.

Parameter yang digunakan dalam Penyusunan Peta Tingkat Kekritisan Lahan yaitu: Peta Kemiringan Lereng (bobot 20\%), Peta Erosi (bobot 20\%), Peta Liputan Lahan (bobot 50\%) dan Peta Manajemen (bobot 10\%). Keempat peta tersebut selanjutnya di-overlay untuk menghasilkan Peta Tingkat Kekritisan Lahan Kawasan Hutan di DAS Pengabuan. Diagram alir analisis data disajikan pada Gambar 1

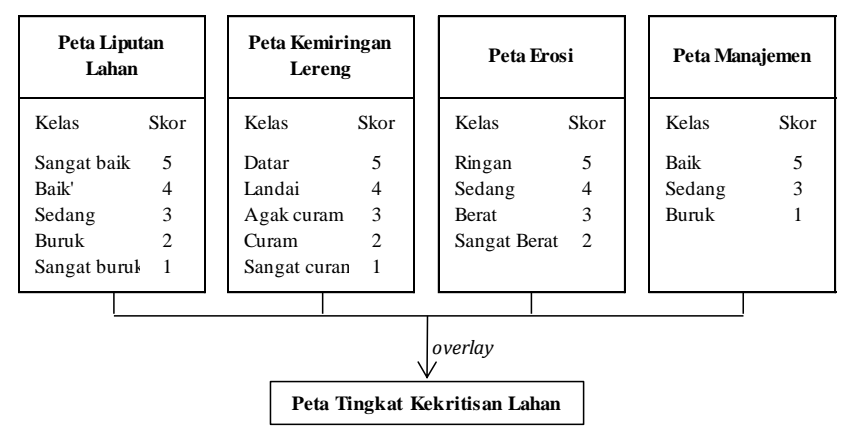

Gambar 1. Diagram alir analisis data

Data lereng, tingkat bahaya erosi dan aspek manajemen bersumber dari dari BPDASHL Batanghari. Parameter liputan lahan dengan bobot $50 \%$ merupakan faktor penting dalam analisis lahan kritis dan merupakan penyederhanaan dari kelas tutupan lahan. Peta penutupan lahan dihasilkan dari dari pengolahan Citra Satelit Landsat 8. Pengolahan citra diawali dengan pra-pengolahan citra yaitu: import data, penggabungan citra, transformasi geometrik, komposit citra dan pemotongan citra dengan batas daerah kajian. Tahap selanjutnya yaitu klasifikasi tutupan lahan secara digital menggunakan metode klasifikasi terbimbing yang dikombinasikan dengan metode visual. Groundcheck dilakukan untuk memverifikasi hasil klasifikasi tutupan lahan agar peta yang dihasilkan akurat. Kelas tutupan lahan selanjutnya disederhanakan menjadi kelas liputan tajuk yaitu: sangat baik, baik, sedang, buruk, dan sangat buruk. Menurut Pertiwi (2013), kelas sangat baik berupa hutan, kelas baik berupa semak/belukar, kelas sedang berupa kebun/perkebunan, kelas buruk berupa ladang/tegalan dan kelas sangat buruk berupa rumput/lahan terbuka, pemukiman dan sawah.
Peta hasil overlay dianalis dan dilakukan klasifikasi skor menggunakan SIG untuk menentukan tingkat kekritisan lahan. Tingkat kekritisan lahan diklasifikasikan ke dalam lima kelas yaitu: sangat kritis, kritis, agak kritis, potensial kritis, dan tidak kritis. Klasifikasi berdasarkan hasil penjumlahan skor dari semua parameter tingkat kekritisan lahan dan dibedakan berdasarkan fungsi kawasan (Tabel 1). Berdasarkan data fungsi kawasan yang diperoleh dari BPDASHL Batanghari, kawasan hutan didalam kawasan lindung yang berada pada DAS Pengabuan yaitu: Taman Nasional Bukit Tigapuluh (TNBT) dan Hutan Lindung Gambut (HLG) Bram Itam. Tingkat kekritisan lahan pada kawasan hutan didalam kawasan lindung dihitung dengan menggunakan rumus: $\Sigma$ skor $=(50 \mathrm{x}$ skor penutupan lahan $)+(20 \mathrm{x}$ skor lereng $)+(20 \mathrm{x}$ skor erosi $)+(10 \mathrm{x}$ skor manajemen $)$.

Pada analisis ini, kawasan hutan diluar kawasan lindung adalah kawasan yang ditetapkan sebagai kawasan hutan yang diusahakan untuk kegiatan produksi. Namun secara prinsip daerah ini masih tetap berfungsi sebagai daerah perlindungan/pelestarian sumberdaya hutan, tanah dan air. Kriteria penilaian kekritisan lahan kawasan hutan diluar kawasan lindung mencakup kawasan hutan produksi yaitu: hutan produksi tetap, hutan produksi yang dapat dikonversi dan hutan produksi terbatas. Tingkat kekritisan lahan pada kawasan hutan diluar kawasan lindung dihitung dengan menggunakan rumus: $\Sigma$ skor $=(50 \mathrm{x}$ skor penutupan lahan $)+$ $(10 \mathrm{x}$ skor lereng $)+(10 \mathrm{x}$ skor erosi $)+(30 \mathrm{x}$ skor manajemen).

Tabel 1. Klasifikasi tingkat kekritisan lahan

\begin{tabular}{ccc}
\hline \multirow{2}{*}{ Tingkat Lahan } & \multicolumn{2}{c}{ Total Skor Pada } \\
\cline { 2 - 3 } Kritis & $\begin{array}{c}\text { Kawasan hutan } \\
\text { didalam kawasan } \\
\text { lindung }\end{array}$ & $\begin{array}{c}\text { Kawasan hutan } \\
\text { diluar kawasan } \\
\text { lindung }\end{array}$ \\
\hline Sangat kritis & $120-180$ & $110-200$ \\
Kritis & $181-270$ & $201-275$ \\
Agak kritis & $271-360$ & $276-350$ \\
Potensial kritis & $361-450$ & $351-425$ \\
Tidak kritis & $451-500$ & $426-500$ \\
\hline Sumber Kemenhut 2013 (modifikasi)
\end{tabular}

Sumber : Kemenhut, 2013 (modifikasi)

\section{Hasil dan Pembahasan}

\subsection{Parameter Kekritisan Lahan}

\subsubsection{Penutupan Lahan}

Penutupan lahan dengan tajuk vegetasi yang rapat mampu menekan peningkatan luas lahan kritis, karena sebesar $50 \%$ bobot penilaian lahan kritis adalah kerapatan tajuk. Ramayanti et al., (2015) menjelaskan bahwa kerapatan vegetasi memiliki peranan penting dalam menekan tingkat kekritisan lahan.

Hasil interpretasi Citra Landsat 8 dan groundcheck lapangan di kawasan hutan DAS Pengabuan diperoleh 4 kelas penutupan lahan yaitu: hutan lahan kering sekunder, hutan tanaman, perkebunan dan lahan terbuka. Informasi penutupan lahan tersebut kemudian dinilai dan diklasifikasikan ke dalam tutupan tajuk pohon, yaitu: sangat baik, baik, sedang dan sangat buruk. Tutupan tajuk sangat baik yaitu hutan sekunder dengan luas 39.282,1 ha.

Hutan sekunder memiliki vegetasi yang rapat sehingga mampu melindungi permukaan tanah. Vegetasi yang dapat dijumpai seperti medang (Litsea sp), mempening (Quercus 
argentata Korth), meranti (Shorea sp), tapus (Elateriospermum tapos) dan lain-lain. Hutan tanaman termasuk tutupan tajuk baik dengan vegetasi cukup baik dan jarak tanam yang cukup rapat $(3 \times 2 \mathrm{~m})$. Luas tutupan tajuk baik yaitu seluas $41.377,4$ ha. Tanaman yang ditanam pada kawasan ini berupa Eucalyptus sp, Acacia crassicarpa dan Acacia mangium. Kelas tutupan tajuk sedang dalam kajian ini yaitu perkebunan. Pada kawasan DAS Pengabuan, jenis perkebunan yang dapat dijumpai berupa perkebunan sawit, karet dan kelapa dengan luas 102.872,2 ha. Kelas tutupan lahan sangat buruk yaitu lahan terbuka dengan luas 4.468,4 ha. Tanah terbuka yang ditemukan di lokasi penelitian sebagai akibat dari pembukaan lahan (land clearing) sehingga tidak ditemukan vegetasi.

\subsubsection{Kemiringan Lereng}

Kemiringan lereng merupakan salah satu penentu terjadinya lahan kritis. Semakin curam lereng semakin besar potensi terjadinya lahan kritis. Kemiringan lereng dapat menjadi penentu cepat atau lambatnya aliran permukaan yang membawa unsur-unsur yang ada di tanah seperti unsur hara, air dan sebagainya. Kawasan hutan di DAS Pengabuan didominasi oleh tingkat kemiringan lereng landai hingga datar. Distribusi kelas lereng yaitu: sangat curam (lereng > 40\%) seluas 47,2 ha, agak curam (lereng 16-25\%) seluas 5.368,5 ha, landai (lereng 9-15\%) seluas 63.865,6 ha dan datar (lereng 0$8 \%$ ) seluas $118.643,5$ ha. Lereng sangat curam berada pada hulu DAS Pengabuan dengan topografi perbukitan. Lereng semakin melandai hingga datar kearah hilir DAS Pengabuan. Dominasi lereng yang datar di DAS Pengabuan menjadi kriteria yang baik dalam menekan tingkat kekritisan lahan.

\subsubsection{Tingkat Bahaya Erosi}

Tingkat bahaya erosi merupakan salah satu penilaian level kerusakan lahan sehingga menjadi penyebab lahan kritis. Menurut Arsyad (2010), erosi merupakan peristiwa pindah atau terangkutnya bagian tanah dari suatu tempat ke tempat lain karena media alami. Dengan demikian, lahan yang tererosi menjadi tidak produktif lagi. Menurut Mulyadi dan Jupri (2016), lahan kritis sebagai akibat dari erosi oleh air hujan. Air hujan telah menghancurkan permukaan tanah yang memiliki penutupan lahan rusak. Berdasarkan data dari BPDASHL Batanghari kelas tingkat bahaya erosi sangat berat di kawasan hutan DAS Pengabuan seluas 886,6 ha, tingkat bahaya erosi berat seluas 54.254,2 ha, tingkat bahaya erosi sedang seluas $24.127,1$ ha dan tingkat bahaya erosi ringan seluas 108.675,7 ha. Berdasarkan data tersebut, kawasan hutan di DAS Pengabuan didominasi dengan kelas tingkat bahaya erosi ringan yaitu sebesar $57,82 \%$ dari keseluruhan luas kawasan hutan.

Tabel 2. Luas tingkat kekritisan lahan tiap fungsi kawasan

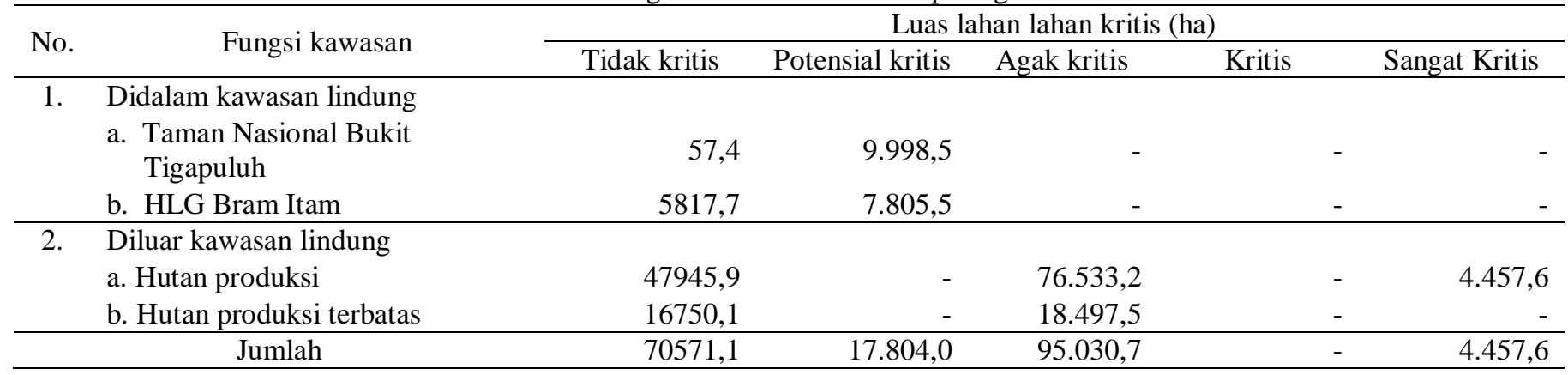

\subsubsection{Manajemen}

Hasil identifikasi dilapangan dan wawancara dengan responden, kawasan dengan tingkat pengelolaan baik adalah kawasan dengan penutupan lahan berupa hutan sekunder dan hutan tanaman seluas $80.659,6$ ha. Kawasan hutan ini meliputi kawasan Taman Nasional Bukit Tigapuluh dan Hutan Lindung Gambut (HLG) Bram Itam yang merupakan kawasan lindung milik negara. Pada kawasan tersebut terdapat tata batas kawasan hutan, pengamanan dan pengawasan hutan, serta dilaksanakannya penyuluhan terkait tata batas kawasan, perlindungan kawasan, fungsi kawasan dan kebakaran atau perambahan hutan.

Kawasan yang memiliki tingkat pengelolaan sedang yaiut pada penutupan lahan perkebunan seluas 10.2872,2 ha. Penilaian kelas sedang berdasarkan adanya penerapan teknik konservasi tanah berupa pembuatan terasering dan jarak tanam yang jelas antar tanaman sehingga dapat mengurangi pengikisan lapisan atas tanah akibat hujan. Pada kawasan ini juga diterapkan pola penanaman yang mengikuti garis kontur sehingga dapat mengurangi kecepatan aliran permukaan. Namun, pada beberapa kawasan perkebunan ini tidak memiliki batasan wilayah yang jelas dan kurangnya pengamanan terhadap kawasan sehingga kawasan ini dikategorikan kelas pengelolaan sedang. Kelas manajemen buruk berada pada lahan terbuka dengan luas 4.468,4 ha. Penilaian katagori kelas buruk dikarenakan vegetasi pohon yang ada sangat rendah (jarang) dan tidak ditemukan kegiatan konservasi tanah dan air. Secara keseluruhan kawasan hutan di DAS Pengabuan didominasi dengan manajemen sedang yaitu sebesar $54,71 \%$ dari total luas daerah penelitian.

\subsection{Sebaran Tingkat Kekritisan Lahan}

Hasil analisis spasial mengindikasikan kawasan hutan di DAS Pengabuan memiliki sebaran lahan kritis dengan tingkatan yang beragam, dari tingkat sangat kritis hingga tidak kritis. Secara umum, kawasan hutan DAS Pengabuan didominasi oleh tingkat kekritisan agak kritis yaitu seluas 95.030,7 ha $(50,58 \%)$, sedangkan kelas sangat kritis yaitu seluas $4.457,6$ ha $(2,38 \%)$ merupakan sebaran tingkat kekritisan yang terkecil. Lahan dengan kelas agak kritis perlu pengelolaan dengan baik agar tidak terkonversi dan menjadi lahan kritis hingga sangat kritis. Sebaran tingkat kekritisan lahan di masing-masing fungsi kawasan disajikan pada Tabel 2. Peta Tingkat Kekritisan Lahan Kawasan Hutan DAS Pengabuan disajikan pada Gambar 2. 


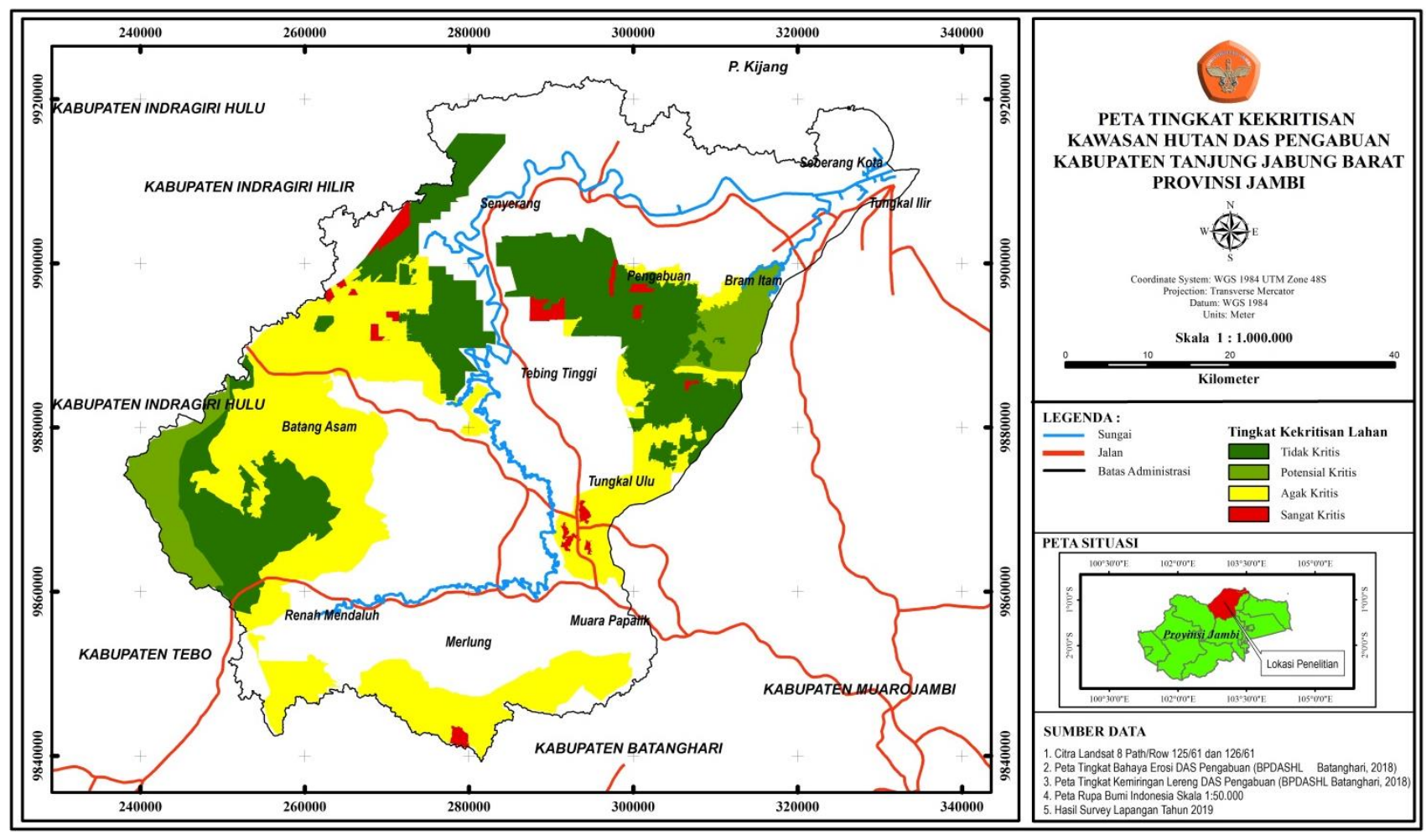

Gambar 2. Peta Tingkat Kekritisan Kawasan Hutan DAS Pengabuan

\subsubsection{Lahan Kritis Pada Kawasan Hutan Didalam Kawasan Lindung}

Kawasan Taman Nasional Bukit Tigapuluh didominasi dengan nilai tingkat kekritisan lahan potensial kritis seluas 9.993,5 ha. Sedangkan pada kawasan HLG Bram Itam didominasi dengan tingkat kekritisan lahan potensial kritis seluas 7.805,5 ha. Secara keseluruhan, pada kawasan hutan didalam kawasan lindung tingkat kekritisan lahan terdiri dari kelas potensial kritis seluas $17.804,0$ ha dan kelas tidak kritis seluas $5.875,1$ ha.

Salah satu faktor penyebab rendahnya tingkat kekeritisan lahan yaitu kondisi lahan kawasan hutan didalam kawasan lindung DAS Pengabuan masih tergolong baik. Tutupan tajuk sangat baik berupa hutan mampu menekan kekritisan lahan. Selain itu, aspek manajemen pengelolaan yang baik juga mempengaruhi hasil penilaian kekritisan pada kawasan ini. Pada HLG Bram Itam, faktor kemiringan lereng yang dominan datar juga berperan meminimalisir potensi lahan kritis. Akan tetapi, tingginya tingkat bahaya erosi dan faktor lereng pada TNBT dapat mengakibatkan kondisi lahan pada kawasan ini menjadi kritis jika parameter penutupan lahan dan manajemen tidak dikelola dengan baik. Pengelolaan dan pengamanan pada kawasan ini perlu ditingkatkan mengingat potensi hutan yang ada dapat terkonversi.

\subsubsection{Lahan Kritis Pada Kawasan Hutan Diluar Kawasan Lindung \\ Berdasarkan peta fungsi kawasan yang diperoleh dari} BPDASHL Batanghari, kawasan hutan diluar kawasan lindung yang berada pada DAS Pengabuan yaitu: hutan produksi dan hutan produksi terbatas. Pada kawasan hutan produksi didominasi kelas agak kritis dengan luas sebsesar 76.533,2 ha. Hasil analisis juga mengidikasikan terdapat lahan dengan tingkatan kelas sangat kritis. Lahan sangat kritis ini disebabkan adanya kegiatan produksi yaitu pemanenan hasil kayu pada hutan tanaman dan kegiatan peremajaan tanaman perkebunan yang sudah tua. Kegiatan produksi tersebut mengakibatkan perubahan tutupan lahan menjadi terbuka dan menurunkan skor dalam penilaian. Namun, kondisi tersebut tidak berlangsung lama dikarenakan adanya kegiatan penanaman kembali yang berdampak pada pulihnya kembali liputan tajuk tanaman dan pada akhirnya mampu menekan lahan kritis.

Kawasan hutan produksi terbatas (HPT) didominasi kelas agak kritis seluas 18.497,5 ha. Pada kawasan ini terdapat tutupan tajuk yang masih baik. Pembukaan lahan yang terjadi dapat mengakibatkan tingkat kekritisan lahan yang ada menjadi sangat kritis. Faktor pendorong yaitu tingginya tingkat bahaya erosi dan kondisi topografi (lereng)

\section{Kesimpulan}

1. Sebesar $95.030,7$ ha $(50,58 \%)$ dari kawasan hutan di pada DAS Pengabuan termasuk dalam kriteria agak kritis.

2. Kawasan hutan didalam kawasan lindung tidak terdapat lahan dengan kriteria agak kritis, kritis dan sangat kritis. Lahan dengan kriteria potensial kritis yaitu seluas 17.804 ha $(75,19 \%)$ mendominasi kawasan hutan didalam kawasan lindung di DAS Pengabuan.

3. Kawasan hutan diluar kawasan lindung memiliki lahan sangat kritis yaitu seluas $4.457,6$ ha $(2,71 \%)$ dengan penutupan lahan tanah terbuka. Sebesar 95.030,7 ha $(57,88 \%)$ kawasan hutan diluar kawasan lindung termasuk dalam kriteria lahan agak kritis.

\section{Ucapan Terimakasih}

Ucapan terimakasih penulis sampaikan kepada Universitas Jambi yang telah memfasilitasi terlaksananya 
kegiatan penelitian ini melalui sumber pendanaan PNBP Fakultas Kehutanan Tahun Anggaran 2019.

\section{Daftar Pustaka}

Ali, M., Hadi, S., dan Sulistyantara, B. 2016. Study on land cover change of Ciliwung downstream watershed with spatial dynamic approach. Procedia - Social and Behavioral Sciences, 227(2016), 52-59.

Anasiru, R. H. 2016. Analisis spasial dalam klasifikasi lahan kritis di kawasan Sub-DAS Langge Gorontalo. Jurnal Informatika Pertanian, 25(2), 261-272.

Arsyad, S. 2010. Konservasi Tanah dan Air (Edisi kedua). Bogor. IPB Press.

Chowdhury, M., Hasan, M. E., Al-Mamun, M. M. A. 2020. Land use/land cover change assessment of Halda watershed using remote sensing and GIS. The Egyptian Journal of Remote Sensing and Space Sciences. 23(2020), 63-75.

Harjianto, M., Sinukaban, N., Tarigan, S. D., dan Oteng Haridjaja, O. 2016. Evaluasi kemampuan lahan untuk arahan penggunaan lahan di Daerah Aliran Sungai Lawo, Sulawesi Selatan. Jurnal Penelitian Kehutanan Wallacea, 5(1), 1-11.

Indrihastuti, D., Murtilaksono, K., dan Tjahjono, B. 2016. Analisis lahan kritis dan arahan rehabilitasi lahan dalam pengembangan wilayah Kabupaten Kendal Jawa Tengah. Jurnal Tata Loka, 18(3), 141-157.

Kementerian Kehutanan. 2013. Peraturan Direktur Jenderal Bina Pengelolaan Daerah Aliran Sungai dan Perhutanan Sosial Nomor: P.4/V-Set/2013 Tentang Petunjuk Teknis Penyusunan Data Spasial Lahan Kritis.

Keputusan Menteri Lingkungan Hidup dan Kehutanan Nomor: SK.306/MENLHK/DAS.0/7/2018 Tentang Penetapan Lahan Kritis Nasional.

Kubangun, S., H., Haridjaja, O., dan Gandasasmita, K., 2016. Model perubahan penutupan/penggunaan lahan untuk identifikasi lahan kritis di Kabupaten Bogor, Kabupaten Cianjur, dan Kabupaten Sukabumi. Majalah Ilmiah Globe Volume, 18(1), 21-32.

Kusuma, A.K. 2019. Analisis Perubahan Tutupan Lahan di DAS Pengabuan Periode 1996-2017. Skripsi. Program Studi Kehutanan Fakultas Kehutanan Universitas Jambi

Mulyadi, A., dan Jupri. 2016. Kajian lahan kritis sub daerah aliran Ci Keruh di Kawasan Cekungan Bandung. Prosiding Seminar Nasional Geografi UMS: Upaya Peningkatan Risiko Bencana Terkait Perubahan Iklim, 238-249.

Pertiwi, A.I. 2013. Identifikasi dan Pemetaan Lahan Kritis Dengan Mengunakan Teknologi Sistem Informasi Geografis dan Penginderaan Jauh (Studi Kasus di Sub DAS Cisadane Hulu, Kabupaten dan Kota Bogor, Provinsi Jawa Barat). Skripsi. Departemen Konservasi Sumberdaya Hutan dan Ekowisata Fakultas Kehutanan Institur Pertanian Bogor.

Ramayanti, L. A, Yuwono, B., D., dan Awaluddin, M. 2015. Pemetaan tingkat lahan kritis dengan menggunakan penginderaan jauh dan Sistem Informasi Geografi (Studi Kasus: Kabupaten Blora). Jurnal Geodesi Undip, 4(2), 200-207.
Renyut, L. R., Kumurur, V. A., dan Karongkong, H., H. 2018. Identifikasi dan pemetaan lahan kritis dengan menggunakan teknologi Sistem Infomasi Geografis (Studi Kasus Kota Bitung). Jurnal Spasial, 5(1), 92104.

Rosyada, M., Prasetyo, Y., dan Hani'ah. 2015. Penentuan tingkat lahan kritis menggunakan metode pembobotan dan Algoritma NDVI (Studi Kasus: Sub DAS Garang Hulu). Jurnal Geodesi Undip, 4(1), 85-94.

Ruhama, A., Numba, S., dan Saida. 2020. Analisis lahan kritis dan arahan penggunaan lahan pada Sub Daerah Aliran Sungai Binanga Lantang di Sulawesi Selatan. Jurnal Agrotek, 4(1), 37-52. 